\title{
What Indonesia Should Learn from China's Social Credit System?: Measuring Government Authorities and Citizen's Privacy Rights
}

\author{
Cokorda Istri Chandra Devi Padmananda* \\ Faculty of Law Udayana University, Bali, Indonesia \\ I Nyoman Suyatna* \\ Faculty of Law Udayana University, Bali, Indonesia
}

Article Received: $4^{\text {th }}$ July 2019; Accepted: $28^{\text {th }}$ January 2020; Published: $31^{\text {st }}$ January 2020

\begin{abstract}
China's Social Credit System (CSC) is a reputation system adopted by the Government of the Peoples' Republic of China that establish a mechanism of rewarding and imposing punishment to its citizen, by taking into account the behavioral performance and compliance to the law and regulation. This article aimed to reviews the concept and the scope of implementation of China's SCS and to analyze the possibility of the Indonesian Government to adopt it into Indonesia's legal system and legal culture. This article reflects a doctrinal legal research that collects primary and secondary sources and uses statutory, comparative, and analytical approaches. This article found that SCS basically aims at creating a comprehensive data based-system to improve the citizen's behavior based on the scoring system that entails rewards and sanctions. The widely accepted of this system by the citizen of PRC, however, does not correspond to a remaining legal issue about the lack of protection of privacy rights, particularly regarding the naming and shaming of a blacklisted person. This article suggests that Indonesia may adopt some China's SCS aspects, including the basic idea of the upgrading of the standard of citizen behavior, the establishment of a comprehensive system that integrating all data, and partial adoption of the data analysis. However, it seems that the naming and shaming for blacklisted persons do not relevant to be adopted by the Indonesian government in the near future, in a consideration of the legal culture in Indonesia and the communal life of the Indonesian peoples.
\end{abstract}

Keywords: Social Credit System; Government Authorities; Rights of Privacy; Peoples' Republic of China; Republic of Indonesia.

How to cite: Devi Padmananda, Cokorda Istri Chandra, and I Nyoman Suyatna. "What Indonesia Should Learn from China's Social Credit System?: Measuring Government Authorities and Citizen's Privacy Rights." Udayana Journal of Law and Culture 4, no. 1 (2020): 104-118. https://doi.org/https://doi.org/10.24843/UJLC.2020.v04.i01.p06.

doi: $\underline{\text { https://doi.org/10.24843/UJLC.2020.v04.i01.p06 }}$

\footnotetext{
*Email/Corresponding Author : cokdevi00@yahoo.com

** Email : nyoman_suyatna@unud.ac.id
} 


\section{Introduction}

\section{I.1 Background}

Term 'privacy' becomes more and more important in the current life of the peoples. Each individual tends not to share or publicly release his/her privacy for security and comfort reasons. In general, there is also an increasing awareness of respecting the privacy rights of others. But, still, a concern of public interests and national security, to some extent, is considered as an exemption.

A controversy raises when the Government Peoples' Republic of China (PRC) issued a policy that introducing a social credit system. A preliminary step was taken by operating more than 200 million surveillance cameras, ${ }^{1}$ to be put mainly in public spaces such as streets, supermarkets, malls, and government buildings across the country. It may watch some practical activities of the peoples: who they meet, what they buy, or what they do. This monitoring mechanism would threaten individual privacy in their lives. ${ }^{2}$

The objective of social credit is to track and value the actions of every people. ${ }^{3}$ It is intended to establish a uniform SCS system based on mechanisms of rewarding and imposing penalties. The SCS inherently entails a far-reaching effect as it enables the blacklisting system.

This national policy is not only implemented at the central level. It urges local government, as well as social and business entities, to take specific action including penalties and limitations to those who were blacklisted. ${ }^{4}$ Further, it is also implemented until the level of the village. ${ }^{5}$ It is, indeed, a huge and systematic system.

A skeptical view on PRC's SCC, mainly from analysts and outsiders, does not parallel to the opinion of Chinese citizens, who have directly experienced this system. The 2018 survey reveals that four out of five (eighty percent) respondents agreed to both government and commercial SCC. Among those who agreed to this system, the wealthy and well-educated citizens as well as the elderly, strongly support SCC. ${ }^{6}$ A village leader

${ }^{1}$ Daithi Mac Sithigh and Mathias Siems. 2019. The Chinese Social Credit System: A Model for Other Countries ?. European University Institute Department of Law, Research Paper No.2019/01.European University Institute, Italy, 13

${ }^{2}$ Detik News, China Bangun Kediktatoran Digital Lewat Sistem Kredit Sosial, 21

September 2018, https://news.detik.com/abc-australia/d-4222035/china-bangunkediktatoran-digital-lewat-sistem-kredit-sosial

${ }^{3}$ Larry Catá Backer, China's Social Credit System: Data-Driven Governance for a 'New Era', Current History (2019), 213

4 Rogier Creemers, 2018, China's Social Credit System: An Evolving Practice of Control, Leiden University-Van Vollenhoven Institute, Netherlands, 15.

5 Sophia Yan, The Village Testing China's Social Credit System: Driven By Big Data, Its Citizens Earn a Star Rating, Post Magazine, 2 June 2019, https://www.scmp.com/magazines/post-magazine/long-reads/article/3012574/villagetesting-chinas-social-credit-system

${ }^{6}$ Genia Kostka, What Do People In China Think About 'Social Credit' Monitoring?, Washington

Post, March

21 , 2019, 
believes that SCC would lead villagers to become better persons because it increases the good-faith as well as moral and family values. ${ }^{7}$

\section{I.2 Purpose}

This article aimed to analyze two main issues. First, it reviews the concept and the scope of implementation of China's Social Credit System (SCS). In addition, it will analyze the possibility of the Indonesian Government to adopt China's SCS in its legal system and culture.

\section{3 Research Method}

This article reflects a doctrinal legal research that collects the various type of legal documents dealing with this topic (primary sources) besides journal articles (secondary sources) that can be seen as normative. ${ }^{8}$ In particular, it uses statutory, comparative, and analytical approaches. The statutory approach is used to analyze relevant legal instruments while the comparative approach is used to compare the situation in China and Indonesia. Lastly, the analytical approach is used to deal with some analysis of legal concepts.

\subsection{Literature Review}

Rogier Creemers studies how the idea as well as to indicate its evolution at the Party-State, both at central and local levels ${ }^{9}$ while Daithí Mac Sithigh and Mathias Siems assess the current and future operation of China's SCS as well as the range of regulatory approaches. ${ }^{10}$

Genia Kostka carried out a survey in 2018 with more than two thousand respondents through in-depth interviews. The study suggests that PRC citizens tend to respond to the SCS in positive thinking. ${ }^{11}$

Karen Li Xan Wong and Amy Shields Dobson conduct comparative research that juxtaposes China SCS and systems that are developed in Western democratic countries.12 They found that despite Western democratic countries do not have a comprehensive system as China's CSP, but the same cultures and structures are already in place in those

https://www.washingtonpost.com/politics/2019/03/21/what-do-people-china-thinkabout-social-credit-monitoring/(Genia Kostka 1)

7 Sophia Yan, loc.cit

8 See Ian Dobinson and Francis Johns,. "Legal Research as Qualitative Research," in Research Methods for Law, ed. Mike McConville (Edinburgh: Edinburgh University Press Ltd, 2006)

${ }^{9}$ Rogier Creemers, op.cit, 3.

10 Daithi Mac Sithigh and Mathias Siems, op.cit, 2

11 Genia Kostka 1, op.cit

12 Karen Li Xan Wong and Amy Shields Dobson, "We're just Data: Exploring China's Social Credit System in Relation to Digital Platform Ratings Cultures in Westernised Democracies," Global Media and China 4, no.2 (2019) : 222. 
countries. ${ }^{13}$

There is a very lack of literature that discusses the impact of CSC to Indonesia. Istigfaro Anjaz Ajizi reviews the impact of CSC on Indonesia. Besides, he predicts Indonesia's future programs to make used big data technology optimally for the national interest. ${ }^{14}$

\section{Result and Analysis}

\subsection{The Concept and the Scope of Implementation of China's Social Credit System}

\subsubsection{The Concept of China's Social Credit System}

The basic idea of China's Social Credit System (SCS) is to create a comprehensive data based-system to improve the citizen's behavior. There are two basic elements of SCS. First of all, a set of data that integrates data held by government and non-governmental bodies all over PRC and the extension of means of collecting data. The second element is a system that ensures the citizens and other entities more earnest and reliable. It creates a comprehensive scoring system for every person's social credit. A total score can be obtained as it integrates a variety of data collection system. ${ }^{15}$

The SCS covers four scopes of measurement to assume whether or not persons comply with the law and social obligation, namely sincerity in government affairs, commercial sincerity, societal sincerity, and judicial credibility. 16 This system assesses the realibilitiness of persons, business and social entities, and government agencies. The big data is exploited to conduct social control and management by virtue of addressing matters in society and preventing social instabilities in a very early stage. ${ }^{17}$

As previously informed, the SCS based on mechanisms of giving reward and imposing punishment based on the scoring system. If a person places a high score in this system, he/she will enjoy some privileges in hotels and airports, low-rate loans, access to higher education, and the best position of employments. ${ }^{18}$ In case a person finds and then returns the lost items to the belonging person, he/she will be attributed some good sign, for

\footnotetext{
13 Ibid, 228.

14 Istigfaro Anjaz Ajizi, China's Social Credit: New Challenges and Benefits, the Jakarta Post, February 27, 2018, https://www.thejakartapost.com/academia/2018/02/27/chinas-social-credit-newchallenges-and-benefits.html

15 Martin Chorzempa, Paul Triolo, and Samm Sacks. 2018. China's Social Credit System: A Mark of Progress or A Threat to Privacy? Policy Brief, Peterson Institute for International Economics. Washington DC, 2 https://www.piie.com / system/files /documents/ pb18-14.pdf.,

16 Larry Catá Backer, op.cit., 210-211.

${ }^{17}$ Genia Kostka, 2019, "China's Social Credit Systems and Public Opinion :Explaining High Levels of Approval," New Media \& Society 21, No. 7 (2019): 2, (Genia Kostka 2)

${ }_{18}$ Detik News, China Bangun Kediktatoran Digital Lewat Sistem Kredit Sosial, 21 September 2018, https://news.detik.com/abc-australia/d-4222035/china-bangunkediktatoran-digital-lewat-sistem-kredit-sosial
} 
example 'helpfulness' and "care-taking for others". ${ }^{19}$

The blacklist is basically imposed by a legally binding Supreme People's Court. Besides, specific Government Ministeries may also execute it. As an example, the Ministry of Culture and Tourism may determine persons who violated rules in transportation, such as smoking or carrying prohibited items. There might also a Joint Punishment System in which breach of regulation entails a multifariousness or tiers of penalties. For example, the first sanction is in begun with imposing a fine and may be continued with a travel ban (flight or high-speed trains). One of the most economically-impact punishments for the blacklisted residents is the restriction to purchase specific goods and kinds of stuff from their bank account. 20

The main website that includes the names of the blacklisted person is publicly available, it means that everyone can access it easily. It is quite clear that such a system infringes on the internationally recognized right of privacy, in which everyone is protected not to be subjected to attacks upon his honor and reputation. ${ }^{21}$ Individuals have grown up over the centuries in the struggle for human rights, and are now protected by international code that the rights to be fit alone, to live one's life as one pleases without interference by the state or its public authorities unless one is doing demonstrable harm to others. ${ }^{22}$

If we look at China's National Law and regulations, there is a provision that protects the citizen's privacy Simply, if a person violates public rules, such as stealing items, blacklisting will be imposed, entails that he/she is not allowed using civil aircraft or high-speed train. According to Article 40 of The Constitution Law of People's Republic of China: "The freedom and privacy of correspondence of citizens of the People's Republic of China are protected by law. No organizations or individual may, on any ground, infringe upon the freedom and privacy of citizens correspondence except in cases where, to meet the needs of state security of investigation into criminal

${ }^{19}$ Severin Engelmann, op.cit, 7

20 Daithi Mac Sithigh and Mathias Siems, op.cit.,13

${ }^{21}$ See Article 12 of the Universal Declaration of Human Rights; Article 17 (1) and (2) of International Covenant on Civil and Political Rights; Article 1 of the Convention for The Individuals about Automatic Processing of Personal Data; Article 16 (1) and (2) of Convention on the Rights of the Child; Article 14 of International Convention on the Protection of the Rights of All Migrant Workers and Members of Their Families; Article 22 (2) of Convention on the Rights of Persons with Disabilities; Article 5 of the American Declaration on the Rights and Duties of Man; Article 10 of the African Charter on the Rights and Welfare of the Child; Article 8 of the African Declaration on Internet Rights and Freedoms; Article 11 of the American Convention on Human Rights; Article 21 of the ASEAN Human Rights Declaration; Article 17 of the Arab Charter on Human Rights; Article 8 (1) and (2) of the European Convention for the Protection of Human Rights and Fundamental Freedoms

22 Paul Siegbart, 1986, The Lawful Rights of Mankind (New York: Oxford University Press, 1986), 161 
What Indonesia Should Learn from China's Social Credit System?:

Measuring Government Authorities and Citizen's Privacy Rights

Cokorda Istri Chandra Devi Padmananda and I Nyoman Suyatna

offenses, public security or procuratorial organs are permitted to censor correspondence in accordance with procedures prescribed by law".

\subsubsection{Scope of Implementation of the China Social Credit System: How Far the Local Governments Take Step?}

Even the local governments do not have all data like what central government has, they still have a big proportion of access in developing systems that connecting the accessed data in their authorities. ${ }^{23}$ Progressive initiatives, even more than what the central government has done, were implemented by many local governments in PRC. then As seen earlier, a considerable number of local governments had initiated social credit initiatives far ahead of the central government, including the city of Ningbo, Shenzhen, and Shanghai.24

Until March 2019, there are 43 cities in PRC, in which local governments have initiated SCC as a mandatory program. ${ }^{25}$ Act of interference was practiced by some cities. In the City of Dengfeng (Henan province), a caller receives an audio message greeting, informing that the intended person to talk with is a not trustable person who has been blacklisted. In the city of Taishan, the photos of the blacklisted persons are 'advertised' in light-emitting diode (LED) billboards and TV screens situated in public spaces. ${ }^{26}$

Local government officials conducted some technical works e.g collecting and uploading data, making a classification, as well as imposing a sanction. Moreover, local tribunals, by taking an example of those in Luoyuan (Fujian Province) and Qichun (Hubei Province), also play a role in naming and shaming the blacklisted person in the local forum and specific means. ${ }^{27}$

The City of Rongcheng (Shandong province) becomes a pilot project. Every single inhabitant at the beginning will be given 1000 points. A person who could reach beyond 1050 points is classified as an ideal resident, while resident who only could reach 849 is considered at the alert situation. The blacklisted persons are residents who scored below 599, which entails that their name will be widely exposed and published publicly, as well as will be thoroughly watched.28

It is, indeed, a huge and systematic mechanism. Whatsoever, a survey reveals that most PRC citizens tend to believe that the central government should steer a nationwide SCS, compare to delegate the authority of taking

\footnotetext{
${ }^{23}$ See Martin Chorzempa, Paul Triolo, and Samm Sacks, loc.cit.

24 Ibid, 17-18.

25 Genia Kostka 1, loc.cit.

${ }^{26}$ Karen Li Xan Wong and Amy Shields Dobson, op.cit., 224.

27 Chuncheng Liu, "Multiple Social Credit Systems in China", Economic Sociology 21, No. 1 (2019): 25

${ }^{28}$ Karen Li Xan Wong and Amy Shields Dobson, op.cit., 223.
} 
it lead to local governments. ${ }^{29}$

\subsection{Would the Concept of Social Credit System be adopted in Indonesia?}

Daithi Mac Sithigh and Mathias Siems argue that the new approach of China SCS should be learned by Westerns, including lawmakers, as a picture to consider the impact of current emphasis upon quantification and reputation across a range of domains, personal and official. ${ }^{30}$ What then Indonesia could learn from China SCS?

Istigfaro Anjaz Ajizi pays attention that CSS includes foreign companies operating in China, in which Indonesian companies that have business relations with the PRC have to learn the CCS and to some extent, adjust and comply with the rules. An issue raises if Indonesian business entities operating in PRC are requested required to disclose their internal information to the Chinese authorities. There may also be a case if Chinese companies that perform their business activities in Indonesia are requested to open their data from Indonesia to the Chinese authorities. Would Indonesia benefit from the big data revolution? Again, as pointed out by Istigfaro Anjaz Ajizi, its legal regime has to be directed clearly not only for the sake of protecting the national interests, but it could ensure the simplify the domestic business. Besides, big data could ensure government transparency and increase public participation in policymaking. ${ }^{31}$

Indonesia does not have legal protection upon personal data. The protections are stipulated in various sectoral regulations. Further, there is either a clear or proper monitoring mechanism over business entities that collect and process personal data in Indonesia. ${ }^{32}$

The chip inside the electronic national identity card (e-KTP) can function as a resident electronic data storage device, including biometric data such as a record of fingerprints. ${ }^{33}$ The national government is striving for a single identity system to build the nation's reputation in the global world. It will establish a single identity number in the various sector by using the population identification number (ID number) that is listed on the eKTP. This card will also be connected to the data contained in the driving license, social health Insurance card, tax, military, police, and the National Land Agency. Until May 2019 the Ministry of Home Affairs has collaborated with 1,210 institutions that have integrated their institutional data with

29 Genia Kostka 1, loc.cit.

30 Daithí Mac Síthigh and Mathias Siems, op.cit., 29-30.

${ }^{31}$ Istigfaro Anjaz Ajizi, loc.cit.

32 Alia Yofira Karunian, Helka Halme, and Ann-Marie Söderholm, " Data Profiling and Elections: Has Data-Driven Political Campaign Gone Too Far?" Udayana Journal of Law and Culture 3, No.1 (2019): 117.

${ }^{33}$ Article 58 (2) and 64 (6) of Law of the Republic of Indonesia No 23 Year 2006 concerning Population Administration as Ammended by Law No. 24 Year 2013. 
population data. The National Amil Zakat Agency is one of the agencies that collaborate with the Ministry of Home Affairs regarding the use of population databases to map muzaki and mustahik zakat. It is hoped that the national zakah service can use fingerprints and ID number only. Director-General of Population and Civil Registration of the Ministry of Home Affairs conveyed the public not to worry about integrating population data with a number of institutions because data confidentiality is guaranteed. ${ }^{34}$

Constitutional Court of the Republic of Indonesia has clarified the norms regarding the right of privacy. The Court repeatedly rules that right of privacy is a type of derogable rights, but its restriction can only be exercised by the Law, as stipulated in Article 28J (2) of the 1945 Constitution of the Republic of Indonesia. The Court examines the issue of privacy rights in dealing with the case of wiretapping. It explicitly rules that wiretapping is a form of violation of the rights of privacy. 35

It is as internationally accepted principles and norms, in which Indonesia also fully respects those, underlining that restrictions on rights for privacy can not be done arbitrarily and that restrictions must meet certain conditions. ${ }^{36}$ In Indonesia, violation of privacy rights may be imposed on various types of punishment, including criminal and administrative sanctions. ${ }^{37}$

What about the China SCS that establishes a reward and punishment system? Rewards to the citizen in Indonesia is not given in an integrated system. Instead, the rewards are given in particular fields. In the field of environment and nature, the National Government Since 1980, gives The Kalpataru Award as the highest appreciation given to individuals and groups who are considered to be instrumental in pioneering, serving, saving and fostering environmental and forestry protection and management. ${ }^{38}$ In security affairs, the police regularly give an award to residents who provide assistance. For example, the honour was given to a public transport driver

${ }^{34}$ E-KTP, Pemerintah Fokus Terapkan Sistem Identitas Tunggal (terkoneksi dengan SIM, BPJS, asuransi, pajak, dan data lain), 14 May 2019,

https://www.e-ktp.com/2019/05/pemerintah-fokus-terapkan-sistem-identitastunggal-terkoneksi-dengan-sim-bpjs-asuransi-pajak-dan-data-lain/

35 Constitutional Court of the Republic of Indonesia, Case No. 5/PUU-VIII/2010, para 3.21.

36 See Damian Agata Yuvens, Rangga Sujud Widigda dan Aisyah Sharifa, Dilema Upaya Hukum Terhadap Penyadapan, Jurnal Hukum dan Pembangunan 47, No. 3 (2017): 298.

37 Alia Yofira Karunian, Helka Halme, and Ann-Marie Söderholm, op.cit, 115

38 Article 6 of the Regulation of the Minister of Environment and Forestry of the Republic of Indonesia No.P.30/MENLHK/SETJEN/KUM.1/4/2017 Concerning The Conferment of Kalpataru Awards and Kementerian Lingkungan Hidup dan Kehutanan Republik Indonesia, 39 Tahun Penghargaan Kalpataru, 11 Juli 2019, https://www.menlhk.go.id/site/single_post/2217 
who caught perpetrator of cellphone grabbing in Jakarta. ${ }^{39}$

Appreciation is also given to professions. In the field of national defense, some dedicated Indonesian citizens who are a member of society, are eligible to be awarded a State Defence Award. ${ }^{40}$ In sports, athletes are protected under the national social security program, mainly for work accident and death matters, following the formal cooperation between Indonesian National Olympic Committee and Badan Penyelenggara Jaminan Sosial (BPJS) Ketenagakerjaan is a public body tasked to protect all workers. ${ }^{41}$

The most area that clearly values the society is taxation, In 2018, the national government gave awards to 31 large taxpayers who are widely known as public figures. The award was aimed to send an implicit message to the public that even though they are known as successful figures or entrepreneurs, but in fact, it is also compliant with tax regulations. ${ }^{42}$ In 2019, some 6 out of the total 30 taxpayers are individuals, while the rests are big corporations. ${ }^{43}$ For individual taxpayers, this kind of award becomes a pride because the large amounts of money that they have paid in the form of tax payments was valuable in the achievement of tax revenue targets and help state revenue. In addition, media reports will increase their reputation and finally, will have an impact to voluntarily increase compliance to the tax ${ }^{44}$. In the City of Bandung, land and building tax relief is given to those who have been contributed to the countries (retirees and veterans) as well as owners of cultural heritage buildings. ${ }^{45}$

In Indonesia, social punishment is developed as a part of the state legal system and customary practice. For example, the Police of DenpasarBali regularly shows the suspected narcotics couriers and dealers to the

39 Devi Nindy Sari Ramadhan, Polrestro Jakbar Beri Penghargaan Warga dan Polisi Berjasa, $\quad$ Antara, $17 \quad$ September 2018 , https://www.antaranews.com/berita/749128/polrestro-jakbar-beri-penghargaan-wargadan-polisi-berjasa

40 Articel 3 (a) and 4 (d) Regulation of the Minister of Defense of the Republic of Indonesia No. 37 Year 2013 Concerning the Conferment of State Defense Awards

41 Putri Syifa Nurfadilah, BPJS Ketenagakerjaan Berikan Pelindungan untuk Atlet Kompas.com, 30 July 2018, https://ekonomi.kompas.com/read/2018/07/30/130400726/bpjs-ketenagakerjaanberikan-pelindungan-untuk-atlet

42 Direktorat Jenderal Pajak, Penghargaan Wajib Pajak untuk Apresiasi Kontribusi Kepatuhan, 7 November 2018, https://www.pajak.go.id/id/artikel/penghargaan-wajibpajak-untuk-apresiasi-kontribusi-kepatuhan

43 Berita Satu, Ini 30 Wajib Pajak Besar RI yang Terima Penghargaan Kemkeu, 13 Maret 2019, https://www.beritasatu.com/ekonomi/542705/ini-30-wajib-pajak-besar-riyang-terima-penghargaan-kemkeu

44 Aditya Wibisono, Makna Apresiasi dan Penghargaan untuk Wajib Pajak, Majalah Pajak, 23 April 2019, https://majalahpajak.net/makna-apresiasi-dan-penghargaan-untukwajib-pajak/

45 Tri Ispranoto, Bukan Hanya Warga Miskin, Veteran Juga Dapat Keringanan Pajak, Detik News, 29 July 2018, https://news.detik.com/berita-jawa-barat/d4139440/bukan-hanya-warga-miskin-veteran-juga-dapat-keringanan-pajak 
members of the society in public spaces along with evidence of various types of drugs. ${ }^{46}$ The policy of imposing social sanctions is complementing the charge of criminal sanctions to perpetrators. Despite critics from human rights advocates, the Chief of Police still continues its policy by arguing that it aims at shaming the perpetrator ashamed and willing to not repeat his actions again, as well as to become a means of public education about the dangers of narcotics. ${ }^{47}$ Another example of social punishment is the execution of whipping (caning) to perpetrators of immoral acts in Aceh as a violation of Qanun ${ }^{48}$ that, for years, executed in a public space. The recent development, the whipping can be executed in a correctional facility (penitentiary), may be attended by members of society (the public) that have been reached 18 years old. ${ }^{49}$ A customary sanction that reflects social publishment is also imposed on those who are considered to violate customary rules of the village. For instance, customary villages in Bali have the rule to impose kasepekang and other types of sanctions on its member who cannot fulfil social and financial obligations to the village community. ${ }^{50}$

Reward and punishment mechanisms have been well-practiced to the performance of civil servants. The Government Regulation determines that civil Servants who have shown loyalty, dedication, skill, integrity, discipline, and work performance in carrying out their duties can be given appreciation. ${ }^{51}$ These dedicated civil servants may be awarded some type of appreciation, including the sign of honor; special promotions; priority opportunity for development competence; and/or opportunity to attend official events and/or State events. ${ }^{52}$ On the contrary, Civil servants who commit disciplinary violations are sentenced to discipline by officials who have the authority to punish. ${ }^{53}$ There is also an ongoing development in which some government departments and state-owned enterprises apply more creative financial remuneration, performance allowance, as well as reward and punishment systems to their servants. ${ }^{54}$

46 Balinews Network, Polresta Denpasar Kembali Pajang Wajah Pengedar Narkoba di Lapangan Renon, 8 September 2019, http://balinewsnetwork.com/2019/09/08/polrestadenpasar-kembali-pajang-wajah-pengedar-narkoba-di-lapangan-renon/

47 Kumparannews, Alasan Kapolresta Denpasar Pajang Bandar Narkoba di CFD: Sanksi Sosial, 2 Maret 2019, https://kumparan.com/kumparannews/alasan-kapolrestadenpasar-pajang-bandar-narkoba-di-cfd-sanksi-sosial-1551503520217472792

48 Qanun Aceh No. 6 Year 2014 concerning Jinayat Law

${ }^{49}$ Article 30 of the Governor Regulation of Aceh Province No. 5 Year 2018 concerning the Implementation of Jinayah Procedural Law

50 See Article 31 (f) Regulation of Bali Province No. 4 Year 2019 concerning Customary Village in Bali

51 Article 231 of the of the Government Regulation of the Republic of Indonesia No. 11 Year 2017 concerning Civil Servants Management

52 Ibid, Article 232.

53 Ibid, Article 229.

54 See for example reward and punishment at PT. Telkom (Indonesian Telecomunication) in Rendra Maulana Suryadilaga Mochammad Al Musadieq Gunawan Eko Nurtjahjono, "Pengaruh Reward dan Punishment Terhadap Kinerja: Studi pada Karyawan 
There are some aspects that Indonesia may adopt from China SCS. First of all, the main purpose of this system is to steer the behavior of the citizen into a better level. The system guides all citizens to act in accordance with law and regulation and to behave in a proper manner. For Indonesia, this may become a tool of social engineering to all Indonesian peoples in achieving a standard way of behaving and create an ideal legal culture. Second, China's SCS establishes a comprehensive system that integrating all data. Such a comprehensive system may be adopted by the Indonesian government in advancing the current e-KTP project. But, it must ensure that the data is collected from available sources and aimed for a public purpose. Looking at the massive implementation of SCS by Chinese local governments, a concern should be given with regards to harmonize the authority between national and local government in Indonesia, especially with regards to the development of regional development information system. ${ }^{55}$ Basically, local government is obliged to acknowledge the public service information, in which the local government may use information and communication technology. ${ }^{56}$ Third, partial adoption of the data analysis. China's SCS applies an analytical means in assessing the collected data from various sources. This may be adopted by the Indonesian government, but not in a quantitative means. The analysis should be limited only to perform cross-checking data that may have been changed or invalid. Therefore, the analysis is not performed to indicate any person deserves to be given an award or to be put on a blacklist.

On the contrary, there is one aspect of Chinese SCS that should not be adopted by Indonesia, at least for the current societal development. It is the naming and shaming in a public space that should be avoided as much as the government can. One hand, it infringes on the right of privacy that is legally protected and on the other hand, it may have a psychological impact not only on the individual who is blacklisted but also for their family and relatives. This may be a serious issue for Indonesian peoples who mostly live in a communal life. In addition, Indonesia upholds the rule of law. This means nobody is subject to arbitrary measures by the government. The punishment should be decided by competence authorities, primarily the court system, to ensure that a person is treated equally before the law and to give a room for the alleged person to defend his/her self before the

PT Telkom Indonesia Witel Jatim Selatan Malang," Jurnal Administrasi Bisnis 39, No.1 (2016) and PT. Kereta Api (Indonesian Railways Company) in Dicky Saputra, Nurlina, Lenny Hasan, "Pengaruh Reward (Penghargaan) dan Punishment (Sanksi) Terhadap Produktivitas Kerja Karyawan PT. Kereta Api Indonesia (Persero) Divisi Regional II Sumatera Barat," Jurnal Manajemen dan Kewirausahaan 8, No.1, (2017)

${ }^{55}$ Article 274 of the Law of the Republic of Indonesia No. 23 Year 2014 concerning Regional Government

56 Ibid, Article 347. 
tribunal bench.

\section{Conclusion}

The China's Social Credit System (SCS) basically aims at creating a comprehensive data based-system to improve the citizen's behavior. It covers four scopes of measurement to assume whether or not persons comply with the law and social obligation, namely sincerity in government affairs, commercial sincerity, societal sincerity, and judicial credibility. ${ }^{57}$ The SCS applies a reward and punishment for Chinese citizens based on the scoring system. Despite a massive implementation and positive response from the majority of its citizens, this system inherently raises a question of the protection of privacy rights, especially with regards to the exposure of a blacklisted person to the public through various means and channels.

Would Indonesia adopt the model of SCS? There are some aspects that Indonesia may adopt from China SCS, including the basic idea of elevating the standard of citizen behavior, the establishment of a comprehensive system that integrating all data, and partial adoption of the data analysis. Yet, by reflecting the current legal culture in Indonesia and the communal life of Indonesian people, China's SCS practices on naming and shaming for blacklisted persons seem not appropriate to be adopted by the Indonesian government in the near future.

\section{BIBLIOGRAPHY}

\section{Book}

Siegbart, Paul. The Lawful Rights of Mankind. New York: Oxford University Press, 1986.

\section{Chapter in an Edited Book}

Dobinson, Ian and Francis Johns. "Legal Research as Qualitative Research." In Research Methods for Law, edited by Mike McConville. Edinburgh: Edinburgh University Press Ltd, 2007

\section{Journal Article}

Creemers, Rogier. "China's Social Credit System: An Evolving Practice of Control." SSRN, http://dx.doi.org/10.2139/ssrn.3175792

Yuvens, Damian Agata, Rangga Sujud Widigda, and Aisyah Sharifa. "Dilema Upaya Hukum Terhadap Penyadapan." Jurnal Hukum \& Pembangunan 47, no. 3 (2018): 289-311.

Dicky Saputra, Nurlina, Lenny Hasan. "Pengaruh Reward (Penghargaan) dan Punishment (Sanksi) Terhadap Produktivitas Kerja Karyawan PT. Kereta Api Indonesia (Persero) Divisi Regional II Sumatera Barat,"

${ }^{57}$ Larry Catá Backer, op.cit, 210-211. 
Jurnal Manajemen dan Kewirausahaan 8, No.1, (2017): 1-14

Engelmann, Severin et al. 2019. "Clear Sanctions, Vague Rewards: How

China's Social Credit System Currently Defines Good and Bad

Behavior." Proceedings of the Conference on Fairness, Accountability, and Transparency (FAT), Atalanta USA, January 2019 Pages 69-78, https://doi.org/10.1145/3287560.3287585

Karunian, Alia Yofira, Helka Halme, and Ann-Marie Söderholm, "Data Profiling and Elections: Has Data-Driven Political Campaign Gone Too Far?" Udayana Journal of Law and Culture 3, No.1 (2019): 95-122. https: / / doi.org/10.24843/UJLC.2019.v03.i01.p05

Kostka, Genia. "China's Social Credit Systems and Public Opinion :Explaining High Levels of Approval," New Media \& Society 21, No. 7 (2019): 1565-1593. https://doi.org/10.1177/1461444819826402

Liu, Chuncheng. "Multiple Social Credit Systems in China," Economic $\begin{array}{lllll}\text { Sociology } & 21, & \text { No. } & 1 & \text { (2019): }\end{array}$ http://dx.doi.org/10.2139/ssrn.3423057

Suryadilaga, Rendra Maulana, Mochammad Al Musadieq, and Gunawan Eko Nurtjahjono. "Pengaruh Reward dan Punishment Terhadap Kinerja (Studi pada Karyawan PT Telkom Indonesia Witel Jatim Selatan Malang)." Jurnal Administrasi Bisnis 39, no. 1 (2016): 156163.

Mac Sithigh, Daithí, and Mathias Siems. "The Chinese Social Credit System: A Model for Other Countries?." The Modern Law Review 82, no. 6 (2019): 1034-1071. https://doi.org/10.1111/1468-2230.12462

Wong, Karen Li Xan, and Amy Shields Dobson. "We're Just Data: Exploring China's Social Credit System in Relation to Digital Platform Ratings Cultures in Westernised Democracies." Global Media and China 4, no. 2 (2019): 220-232. https://doi.org/10.1177/2059436419856090

\section{Website Content}

Backer, Larry Catá, China's Social Credit System: Data-Driven Governance for a 'New Era', Current History (2019), http://www.currenthistory.com/Backer-CH2019.pdf

Balinews Network, Polresta Denpasar Kembali Pajang Wajah Pengedar Narkoba di Lapangan Renon, Last Modified September 8, 2019 http://balinewsnetwork.com/2019/09/08/polresta-denpasarkembali-pajang-wajah-pengedar-narkoba-di-lapangan-renon/

Berita Satu, Ini 30 Wajib Pajak Besar RI yang Terima Penghargaan Kemkeu, Last Modified Maret 13, 2019.

https://www.beritasatu.com/ekonomi/542705/ini-30-wajib-pajak-besar-riyang-terima-penghargaan-kemkeu

Chorzempa, Martin, Paul Triolo, and Samm Sacks. 2018. China's Social Credit System: A Mark of Progress or A Threat to Privacy? Policy Brief, Peterson Institute for International Economics. Washington DC. https://www.piie.com/system/files/documents/ pb18-14.pdf.

Detik News, China Bangun Kediktatoran Digital Lewat Sistem Kredit Sosial, Last Modified September 21, 2018. https://news.detik.com/abcaustralia/d-4222035/china-bangun-kediktatoran-digital-lewatsistem-kredit-sosial 
Direktorat Jenderal Pajak, Penghargaan Wajib Pajak untuk Apresiasi Kontribusi Kepatuhan, Last Modified November 7, 2018. https://www.pajak.go.id/id/artikel/penghargaan-wajib-pajak-untukapresiasi-kontribusi-kepatuhan

E-KTP, Pemerintah Fokus Terapkan Sistem Identitas Tunggal (terkoneksi dengan SIM, BPJS, asuransi, pajak, dan data lain), Last Modified May 14. 2019, https://www.e-ktp.com/2019/05/pemerintah-fokusterapkan-sistem-identitas-tunggal-terkoneksi-dengan-sim-bpjsasuransi-pajak-dan-data-lain/

Ispranoto, Tri, Bukan Hanya Warga Miskin, Veteran Juga Dapat Keringanan Pajak, Detik News, Last Modified July 29, 2018. https://news.detik.com/berita-jawa-barat/d-4139440/bukan-hanyawarga-miskin-veteran-juga-dapat-keringanan-pajak

Kementerian Lingkungan Hidup dan Kehutanan Republik Indonesia, 39 Tahun Penghargaan Kalpataru, Last Modified Juli 11. 2019, https://www.menlhk.go.id/site/single_post/2217

Kostka, Genia, What do people in China think about 'social credit' monitoring?, Washington Post, Last Modified March 21, 2019. https://www.washingtonpost.com/politics/2019/03/21/what-dopeople-china-think-about-social-credit-monitoring/

Kumparannews, Alasan Kapolresta Denpasar Pajang Bandar Narkoba di CFD: Sanksi Sosial, Last Modified Maret 2, 2019.https://kumparan.com/kumparannews/alasan-kapolrestadenpasar-pajang-bandar-narkoba-di-cfd-sanksi-sosial1551503520217472792

Nurfadilah, Putri Syifa, BPJS Ketenagakerjaan Berikan Pelindungan untuk Atlet Kompas.com, Last Modified July 30, 2018. https://ekonomi.kompas.com/read/2018/07/30/130400726/ bpjs-ketenagakerjaan-berikan-pelindungan-untuk-atlet

Ramadhan, Devi Nindy Sari, Polrestro Jakbar beri penghargaan warga dan polisi berjasa, Antara, Last Modified September 17, 2018. https://www.antaranews.com/berita/749128/polrestro-jakbar-beripenghargaan-warga-dan-polisi-berjasa

Wibisono, Aditya, Makna Apresiasi dan Penghargaan untuk Wajib Pajak, Majalah Pajak, Last Modified April 23, 2019. https://majalahpajak.net/makna-apresiasi-dan-penghargaan-untukwajib-pajak/

Yan, Sophia, The Village Testing China's Social Credit System: Driven By Big Data, Its Citizens Earn a Star Rating, Post Magazine, Last Modified June 2, 2019, https://www.scmp.com/magazines/postmagazine/long-reads/article/3012574/village-testing-chinas-socialcredit-system

\section{Legal Documents}

International Covenant on Civil and Political Rights

Universal Declaration of Human Rights

The Constitution Law of People's Republic of China, translation https://www.wipo.int/edocs/lexdocs/laws/en/cn/cn147en.pdf

Law of the Republic of Indonesia No 23 Year 2006 concerning Population 
Administration as Ammended by Law No. 24 Year 2013.

Law of the Republic of Indonesia No. 23 Year 2014 concerning Regional Government

Government Regulation of the Republic of Indonesia No. 31 Year 2013 Concerning the Implementation of Law Number 6 Year 2011 concerning Immigration

Government Regulation of the Republic of Indonesia No. 11 Year 2017 concerning Civil Servants Management

Regulation of the Minister of Defense of the Republic of Indonesia No. 37 Year 2013 Concerning the Conferment of State Defense Awards

Regulation of the Minister of Environment and Forestry of the Republic of Indonesia No.P.30/MENLHK/SETJEN/KUM.1/4/2017 concerning The Conferment of Kalpataru Awards

Regulation of Financial Services Authority No. 42 /POJK.03/2017 concerning Obligations For Arrangement and Implementation of Credit Policies or Bank Financing For Commercial Banks

Qanun Aceh No. 6 Year 2014 concerning Jinayat Law

Regulation of Bali Province No. 4 Year 2019 concerning Customary Village in Bali

Governor Regulation of Aceh Province No. 5 Year 2018 concerning the Implementation of Jinayah Procedural Law

\section{Case Law}

Constitutional Court of the Republic of Indonesia, Case No. 5/PUUVIII/2010 